\title{
Participatory Culture dalam Komunitas Online sebagai Reperesentasi Kebutuhan Manusia
}

\author{
Yanuar Herlambang, S.Sn. \\ Dosen Program Studi Manajemen Informatika \\ Politeknik LP3I Bandung \\ e-mail: herlambangyanuar@yahoo.com; pandawadesign@yahooo.com
}

\begin{abstract}
Abstrak: Manusia pada dasarnya adalah mahluk sosial. Dalam kehidupan tradisional, kecenderungan manusia hidup secara sosial terlihat dari aktivitas kesehariannya yang membutuhkan interaksi dengan manusia lainnya seperti dalam pemenuhan kebutuhan dasar. Mereka berusaha mencari koneksitas dengan manusia lainnya dalam pencarian kebutuhan tersebut walaupun mereka berbeda lingkungan dan tidak saling mengenal, proses tersebutlah yang kemudian membentuk komunitas-komunitas yang merupakan kelompok sosial dari beberapa organisme yang berbagi lingkungan yang umumnya memiliki ketertarikan yang sama.
\end{abstract}

Perkembangan teknologi terutama Internet memberikan dampak yang besar terhadap budaya masyarakat dalam beraktivitas, pertumbuhan media ini memberikan pengaruh terhadap budaya masyarakat dalam berinteraksi dan berkomunikasi. Dengan berbagai perkembangan media internet seperti social media, blog, microblog, web-communities, portal dan sebagainya, masyarakat dapat dengan mudah berinteraksi secara online atau langsung pada saat yang sama tanpa ada batasan geografis, ruang maupun waktu, mereka dapat berbagi apapun secara "real-time", terlebih dengan perkembangan gadget yang makin memudahkan masyarakat untuk saling terkoneksi. Interaksi antar individu di dunia maya dapat dikatakan sebagai proses merepresentasikan diri melalui medium media digital internet, bukan presentasi fisikal. Kemudahan koneksi yang terus berkembang merubah budaya beraktivitas sosial seperti kemudahan dalam berbagi terhadap berbagai permasalahan yang ada disekitar mereka dan membuka peran aktif anggotanya untuk membangun solusi atau sebuah tujuan bersama.

Kata kunci: Kebutuhan Manusia; Internet; Komunitas; Partisipatori

\section{Pendahuluan}

Sebelum ada perkembangan teknologi informasi seperti pada masa kini, masyarakat dalam menjalankan aktivitas sosialnya memiliki berbagai keterbatasan dan dengan cakupan yang sempit, termasuk dalam pemenuhan berbagai kebutuhan dasarnya, dalam perjalanannya manusia mengembangakan berbagai ilmu pengetahuan dan teknologi yang makin memudahkan manusia untuk saling terhubung.

Perkembangan teknologi informasi ini memberikan dampak yang besar terhadap budaya masyarakat dalam beraktivitas, salah satunya adalah pertumbuhan internet 
sebagai media yang memberikan pengaruh terhadap budaya masyarakat dalam berkomunikasi yang pada awalnya terbatas hanya menggunakan media konvensional saat ini dapat menggunakan media digital.

Awalnya media online seperti internet dipergunakan dalam kepentingan internal militer dan instansi pemerintahan sebagai sistem yang terintegrasi, kemudian dalam perjalanannya dikembangankan untuk digunakan masyarakat sipil dalam berinteraksi dengan lebih banyak individu lainnya dalam berbagai aktivitas. Interaksi antar individu didalam media online tersebut umumnya dikenal sebagai interaksi dalam dunia virtual atau dunia maya dimana mereka merepresentasikan diri melalui medium media digital internet, bukan presentasi fisik secara langsung.

Dengan dikembangkannya berbagai teknologi berbasis sistem informasi makin membuka berbagai potensi penggunaan teknologi tersebut untuk kebutuhan manusia secara lebih beragam dan luas, terutama dalam konteks manusia sebagai mahluk sosial. Menarik untuk membahas kebutuhan apa saja yang berpotensi dapat terpenuhi oleh perkembangan teknologi informasi ini, bagaimana perannya dalam pembentukan komunitas dari individu-individu yang terhubung, budaya yang bagaimana yang berkembang didalam komunitas tersebut, dan potensipotensi seperti apa yang muncul akibat dari kombinasi aspek yang beragam tersebut.

\section{Pembahasan}

Setidaknya ada empat pembahasan yang diharapkan dapat menjelaskan mengenai uraian dipaparkan dalam pendahuluan diatas, yaitu mengenai kebutuhan dasar manusia, perkembangan internet dan kebudayaan digital, keberadaan komunitas online, dan perkembangan budaya partisipatori.

\subsection{Kebutuhan Manusia}

Dinamika kehidupan yang makin kompleks memberikan pula percepatan signifikan terhadap perubahan didalam kebudayaan. Dalam pendekatan kebutuhan dasar manusia oleh Maslow dalam Sarwono (2002), manusia termotivasi untuk memenuhi kebutuhan-kebutuhan hidupnya, kebutuhankebutuhan tersebut memiliki tingkatan atau hirarki, mulai dari yang paling rendah (bersifat dasar/fisiologis) sampai yang paling tinggi (aktualisasi diri).

Pada tingkat yang paling bawah atau kebutuhan yang paling dasar (basic needs) adalah kebutuhan yang bersifat fisiologis contoh dari seperti: sandang/pakaian; pangan/makanan; papan/rumah, dan kebutuhan biologis seperti: buang air besar; buang air kecil; bernafas; seks; dan lain sebagainya. Kemudian selanjutnya kebutuhan akan rasa aman atau keselamatan (safety needs), kebutuhan ini menampilkan diri dalam kategori kebutuhan akan kemantapan, perlindungan, kebebasan dari rasa takut, cemas dan kekalutan; kebutuhan akan struktur, ketertiban, hukum, batas-batas, dan sebagainya. Yang ketiga adalah kebutuhan sosial yang mencakup kebutuhan akan rasa memiliki-dimiliki, saling percaya, cinta, dan kasih sayang (belongingness and love needs) akan menjadi motivator 
penting bagi perilaku. Yang keempat adalah mempunyai kebutuhan akan penghargaan atau menginginkan penilaian terhadap dirinya yang mantap, mempunyai dasar yang kuat, dan biasanya bermutu tinggi, akan rasa hormat diri atau harga diri (estem needs). Dalam diri manusia selalu memiliki motivasi untuk selalu melebihi dari apa yang mereka telah dapatkan, kebutuhan tertinggi manusia adalah untuk bertumbuh, berkembang, dan menggunakan kemampuannya atau disebut juga sebagai aktualisasi diri (self actualization) .

Maslow juga menyebut aktualisasi diri sebagai hasrat untuk makin menjadi diri sepenuh kemampuan sendiri, menjadi apa menurut kemampuan yang dimiliki. Kebutuhan akan aktualisasi diri ini biasanya muncul setelah kebutuhan akan cinta dan akan penghargaan terpuaskan secara memadai.

Kebutuhan-kebutuhan tersebut yang mendorong manusia memanfaatkan perkembangan yang ada beserta potensi-potensinya dengan melibatkan berbagai penerapan ilmu pengetahuan dan teknologi, tidak hanya berdasar fungsi fisik semata akan tetapi hingga ranah psikologis manusia. Perkembangan teknologi informasi seperti internet kemudian menjadikan kebutuhan-kebutuhan manusia seperti kebutuhan sosial semakin mudah didapatkan.

Contohnya dalam perkembangan kebiasaan selfie atau mempublikasi foto diri di dalam sosial media, kebiasaan ini terpacu akan kebutuhan akan perhatian dari orang lain ataupun rasa menginginkan penghargaan atau penilaian terbaik terhadap dirinya. Begitupun dengan kebiasaan mengungkapkan perasaan, uneguneg atau emosi ke dalam status di sosial media untuk mendapatkan simpati ataupun dukungan dari orang lain.

Dalam penelitian Maslow selanjutnya manusia setidaknya memerlukan beberapa meta-kebutuhan yang harus dimiliki untuk menjaga stabilitas manusia dari sisi psikologis, kebutuhan-kebutuhan tersebut menurut Maslow adalah:

1. Kebenaran.

2. Kebaikan.

3. Keindahan/kecantikan

4. Keseluruhan (kesatuan/integrasi).

5. Dikhotomi-Transendensi

6. Berkehidupan (berproses; berubah tetapi pada esensinya.

7. Keunikan.

8. Kesempurnaan (perfeksi)

9. Keniscayaan

10. Penyelesaian

11. Keadilan

12. Keteraturan

13. Kesederhanaan

14. Kekayaan (banyak variasi, majemuk, tidak ada yang tersembunyi, semua sama penting) 
15. Tanpa susah payah (santai, tidak tegang)

16. Bermain (fun, rekreasi, humor)

17. Mencukupi diri sendiri.

Hal-hal tersebut yang saat ini mulai menjadi tujuan-tujuan secara khusus yang diterapkan kedalam produk-produk teknologi yang dikonsumsi masyarakat, termasuk dalam perkembangan teknologi informasi, hal tersebut terlihat salah satunya dari budaya instant yang berkembang.

Kebutuhan manusia lainnya yang secara baik ditangkap oleh pengembang teknologi adalah game. Saat ini bertaburan permainan-permainan online yang bahkan dapat ditanam didalam sebuah aplikasi sosial media ataupun layanan surat elektronik.

\subsection{Internet dan kebudayaan digital}

Sejarah pengembangan internet tidak dapat lepas dari hasil invensi kode sandi Samuel Morse tahun 1843, yang menjadi salah satu kunci penting bagi inventor-inventor selanjutnya untuk merumuskan cara pengiriman data dalam bentuk yang lebih cepat, efisien dan akurat (Surjomihardjo, et.all., 2002). Penggunaan awal dari kode-kode sandi ini adalah sebagai kepentingan pengiriman pesan rahasia khususnya pada masa perang tahun 1940an. Kepentingan sipil mulai populer setelah 30 tahun kemudian dan mengalami perkembangan mendunia, ketika pada tahun 1991 Berners-Lee dari Cern Laboratory Switzerland, mengembangkan bahasa pemrograman Hypertext Markup Language (HTML) yang memungkinkan jaringan komunikasi antar sistem komputer yang berbeda (Straubhaar \& LaRose, 2008).

Menurut Kotler dan Armstrong (2004), Internet adalah jaringan global dari jaringan-jaringan komputer yang luas dan berkembang tanpa ada manajemen atau kepemilikan terpusat. Internet dapat terintegrasi dengan penggunanya dengan menggunakan jaringan website atau dikenal dengan protokol World Wide Web (WWW), dimana menurut Turban, Rainer, \& Potter (2003) WWW adalah sebuah aplikasi yang menggunaan fungsi transportasi dari Internet dengan pengertian sebuah sistem dengan standar yang diterima secara universal untuk menyimpan, mengambil, memformat, dan menampilkan informasi melalui arsitektur client server.

Internet kemudian berkembang dengan penggunaan teknologi web 2.0 dimana semua orang dapat berperan serta di dalam dunia maya. Internet menjadi media baru yang menfasilitasi pengirim dan penerima dengan penggabungan media tradisional, teknologi computer, dan internet secara interaktif (Peter \& Linda, 1998), sehingga memungkinkan individu-individu di seluruh penjuru bumi, sekalipun menggunakan sistem operasi komputer berbeda, dapat saling bertukar berbagai informasi, berbagi pengalaman hidup dan membangun realitas komunitas maya. 
Dengan perkembangan teknologi inilah terbentuk budaya digital, dimana semua orang dapat melakukan lebih banyak kegiatan yang dahulu hanya dapat dilakukan secara tradisional menjadi cara digital. Internet dapat menghubungkan individu-individu dan komunitas satu sama lain dan dengan informasi secara menyeluruh di dunia. Bagi suatu komunitas, Internet digunakan untuk menjaga dan membangun hubungan dengan anggota aktif dan pasif serta dengan pihak pendukung lainnya dengan lebih efektis dan efisien.

Perkembangan ponsel atau telepon pintar menjadi bukti nyata perkembangan teknologi semakin maju, dahulu untuk mengakses internet kita harus terhubung dengan PC yang terkoneksi dengan jaringan internet menggunakan satelit atau kabel, dengan berbagai keterbatasan masyarakat untuk mengakses internet bahkan sempat berkembang warnet atau warung internet untuk pengguna yang hanya sekedar ingin chat atau berbincang-bincang dengan orang lain secara online.

Saat ini dengan hanya memiliki smartphone android murah pengguna sudah dapat mengakses berbagai kemudahan mulai dari sekedar berbincang, bertukar foto, suara, video, hingga bertukar posisi realtime dengan anggota lainnya dalam komunitas online.

\subsection{Komunitas online}

Jika dilihat dari pemahaman mengenai komunitas secara tradisional, komunitas adalah sebuah kelompok sosial dari beberapa organisme yang berbagi lingkungan, umumnya memiliki ketertarikan yang sama. Dalam komunitas manusia, individu-individu di dalamnya dapat memiliki maksud, kepercayaan, sumber daya, preferensi, kebutuhan, risiko dan sejumlah kondisi lain yang serupa. Menurut Kertajaya Hermawan (2008) "pengertian komunitas adalah sekelompok orang yang saling peduli satu sama lain lebih dari yang seharusnya, dimana dalam sebuah komunitas terjadi relasi pribadi yang erat antar para anggota komunitas tersebut karena adanya kesamaan interest atau values".

Melalui pendekatan sosiologi komunitas dapat dipahami sebagai sebuah kelompok sosial dari beberapa organisme yang berbagi lingkungan, umumnya memiliki ketertarikan yang sama. Menurut Vanina Delobelle (2008), definisi suatu komunitas adalah group beberapa orang yang berbagi minat yang sama, yang terbentuk oleh 4 faktor, yaitu:

1. Komunikasi dan keinginan berbagi (sharing), yaitu para anggota saling menolong satu sama lain.

2. Tempat yang disepakati bersama untuk bertemu.

3. Ritual dan kebiasaan, yaitu orang-orang datang secara teratur dan periodik.

4. Influencer, yaitu merintis sesuatu hal dan para anggota selanjutnya ikut terlibat. 
Berangkat dari pengertian komunitas secara tradisional, terdapat beberapa perbedaan mendasar dengan komunitas online, menurut Jasmadi (2008) komunitas online atau komunitas virtual adalah sekelompok orang dalam berkomunikasi menggunakan internet sebagai media utama dan tidak mengandakan pertemuan langsung secara fisik, beberapa definisi lain komunitas online adalah interaksi antara pengguna melalui jaringan internet dan menurut Laudon dan Traver (2003) komunitas online adalah area dimana orang-orang dapat berbagi pendapat dan dapat berinteraksi secara online.

Dalam komunitas online individu-individu dari berbagai organisme seakanakan hadir duduk bersama saling mengekpresikan diri dan mengembangkan "pengalaman" bersama, dimana teknologi komputer dan internet menjadi infrastruktur dari dibangunnya suatu ranah virtual bagi komunitas maya. Persamaan antara komunitas virtual dengan komunitas fisik / umum menurut Turban, et.aI (2006) adalah seperti tetangga, klub, organisasi, tetapi orangorang tidak bertemu (tatap muka secara langsung). Komunitas virtual menawarkan beberapa cara kepada anggotanya untuk berinteraksi, bekerjasama, ataupun berdagang.

Menurut Laudon dan Traver (2003), komunitas online dapat dikelompokkan melalui beberapa cara, salah satunya adalah dengan mengelompokan anggota komunitas berdasarkan kategori tertentu. Terdapat 5 kategori yang dapat dikelompokkan adalah sebagai berikut :

1. General community, dimana komunitas ditujukan untuk umum menawarkan kesempatan pada anggotanya untuk saling berinteraksi secara umum dengan siapa saja dari anggota komunitas dengan topik bebas. Sehingga anggota akan dapat menemukan ratusan topik-topik diskusi yang sangat beragam dan diskusi grup para anggota yang menshare ide-ide, cerita, informasi, atau pengetahuannya.

2. Practice communities atau komunitas yang menawarkan anggotanya dapat melakukan focus group discussion secara online, diskusi, saling menolong, dan memberikan sharing pengetahuan antar anggota. Contohnya komunitas non profit Open source yang mengembangkan dengan melibatkan ribuan programmer yang membuat dan mengembangkan kode-kode komputer untuk sistem operasi linux dan berbagi hasil secara cuma-cuma dengan web Linux dengan web www[dot]linux[dot]org.

3. Interest communities, komunitas diskusi berdasarkan pada berbagai topik yang spesifik yang sesuai dengan minat atau ketertarikan dan masing-massing anggotanya, contohnya seperti komunitas pecinta alam, kapal, kuda, kesehatan.

4. Affinity communities atau komunitas berdasarkan kesamaan identitas anggotanya atau kelompok.

5. Sponsored communities, jenis komunitas yang dibangun misal oleh pemerintah, perusahaan dengan orientasi non-profit ataupun 
perusahaan komersil yang mengikut-sertakan pengguna produknya dalam pengembangan produk-produk yang diproduksinya.

Di indonesia komunitas online populer dapat kita lihat pada kaskus, komunitas ini memiliki banyak forum-forum yang aktif dengan berbagai topik atau thread, bahkan berkembang pula budaya komunikasi yang ekslusif diantara mereka seperti istilah-istilah khusus untuk panggilan misalnya agan ataupun ungkapan penghargaan ataupun hinaan terhadap anggota lainnya misalnya cendol dan bata.

\subsection{Participatory Culture}

Media online saat ini memberikan kemungkinan-kemungkinan jenis interaksi yang lebih kompleks seperti komentar, diskusi, jajak pendapat, berbagi tulisan dan foto, dan sebagainya. Aktivitas ber-komunitas menjadi lebih "hidup" dengan komunikasi dua arah, dimana para anggota komunitas dapat saling memberikan kontribusi secara langsung kepada anggota lainnya dan berjalannya komunitas.

Dengan berbagai keuntungan yang ditawarkan media online dalam proses komunikasi, interaksi dan koneksi antar individu kemudian membuat media ini menjadi media yang tepat bagi pembentukan dan pengembangan komunitas-komunitas manusia dikarenakan jangkauannya lebih luas dan lebih efisien, dimana dalam komunitas manusia individu-individu di dalamnya dapat memiliki maksud, kepercayaan, sumber daya, preferensi, kebutuhan, risiko dan sejumlah kondisi lain yang serupa. Berbagai fitur yang berkembang didalam media digital internet yang membuka seluas-luasnya bagi para penggunanya mengeksplorasi bentuk interaksi dan komunikasi dengan individu lainnya menjadikan participatory culture berkembang lebih luas dan memiliki wadahnya didunia virtual.

Istilah participatory culture atau budaya partisipatori atau partisipatif memang masih asing di telinga kita, pengertian budaya ini agak bertentangan dengan pengertian budaya Konsumen dimana terdapat pembagian yang jelas antara produsen dengan konsumen. Akan tetapi pada perkembangannya dalam budaya partisipatori ini user atau anggota dalam komunitas online bertindak tidak hanya sebagai pengguna atau konsumen, akan tetapi sekaligus juga sebagai kontributor bahkan produser dan dapat mempublikasikan media tersebut dengan mudah.

Bentuk partisipatori menurut Jenkins, et.al (2005) dapat dinyatakan dengan 4 aspek:

1. Affiliations, dimana keanggotaan, formal atau informal, dalam komunikasi online terpusat.

2. Expressions, memproduksi bentuk kreativitas baru. 
3. Collaborative Problem-solving, membuka peluang bekerja dalam tim, formal atau informal, untuk menyelesaikan sebuah tugas dan mengembangkan pengetahuan.

4. Circulations, membentuk aliran media.

Adapun sifat-sifat yang menyatakan budaya partisipatori adalah sebagai berikut:

1. Memberikan kemudahan akses untuk berekspresi dan pengembangan kepentingan bersama.

2. Dukungan yang kuat dalam berkarya dan berbagi kreasi dengan yang lainnya.

3. Membuka peluang pengembangan konsep mentor antar anggota.

4. Anggota meyakini kontribusinya akan berarti bagi yang lainnya.

5. Memperkuat hubungan sosial sesama anggota, rasa menghargai karya.

6. Tidak ada tekanan untuk berkontribusi, akan tetapi tetap memberi kesempatan dan dorongan untuk berkontribusi.

Dalam aplikasi Waze misalnya anggotanya dapat berkontribusi untuk menginformasikan keadaan lalu lintas ditempat ia sedang berada kepada anggota lainnya secara realtime dengan posisi yang relatif akurat dengan bantuan teknologi gps yang tertanam dalam smartphone mereka, komunitas juga dapat saling berkomunikasi secara online layaknya perbincangan virtual. Tanpa perlu menunggu informasi dari dinas lalu lintas misalnya mereka sudah dapat menerima informasi yang lebih akurat secara realtime mengenai jalan mana yang macet dan mana yang lancar karena partisipasi aktif dari para anggotanya dan kemampuan menjaga kepercayaan antar anggota dalam memberi informasi kepada anggota lainnya.

Budaya partisipatori ini sangat sejalan dengan perkembangan komunitas online dimana terdapat banyak peluang-peluang baru yang tumbuh dalam banyak aspek dibandingkan perkembangannya dalam media tradisional.

\section{Kesimpulan dan Saran}

Komunitas online berkembang pesat dalam masyarakat internasional tidak terkecuali di Indonesia seiring juga dengan perkembangan budaya partisipatori atau peran aktif, dengan segala kelebihan yang ditawarkan media online internet atau perkembangan teknologi sistem informasi potensi budaya partisipatori ini akan berkembang lebih luas lagi. Perkembangan aspek komunitas maupun budaya partisipatori tersebut tidak terlepas dari keinginan manusia untuk selalu memperbaiki atau meningkatkan standar kualitas hidup mereka dalam hal ini memenuhi segala kebutuhannya dengan berbagai cara.

Di dalam budaya partisipatori terdapat banyak potensi yang dapat dikembangkan untuk kebaikan manusia atau komunitas, akan tetapi tidak berarti terbebas dari potensi penyalahgunaan. Budaya partisipatori dalam komunitas online memiliki peran positif maupun negatif, untuk itu perlu dipersiapkan bagaimana dampak buruknya dan bagaimana antisipasinya. Contoh lain terhadap perubahan yang 
mengarah pada keburukan beberapa diantaranya seperti berkembangnya bahasabahasa yang merusak tatanan bahasa yang lazim digunakan, perubahan terhadap etika berkomunikasi secara kasar dikarenakan adanya fitur anonymous terutama bagi remaja ataupun tersebarnya informasi palsu menyesatkan tanpa filter validalitas yang kuat.

Perubahan kearah kebaikan sangat perlu dikembangkan bersama, karena dengan adanya budaya partisipatori dalam komunitas online akan terjadi percepatan arus informasi yang diterima oleh para anggotanya dan dapat bersama-sama dikembangkan dan kemudian menghasilkan sebuah desain solutif terhadap berbagai permasalahan, atau dapat "ditularkan" kepada individu lainnya untuk menjadi bahan pemikiran yang lebih komprehensif dan tepat sasaran baik untuk kepentingan komersil ataupun sosial kemanusiaan.

\section{Daftar Pustaka}

[1] Albrechtslund, A. 2008. Online Social Networking as Participatory Surveillance. Chicago: First Monday.

[2] Barker, Chris. 2000. Cultural Studies, Theory and Practice. London: Sage.

[3] Jasmadi. 2008. Membangun Komunitas Online Secara Praktis dan Gratis. Jakarta: Elex Media.

[4] Jenkins, et.al. 2005. Confronting the Challenges of Participatory Culture: Media Education for the 21st Century. Online: http://www.newmedialiteracies.org/files/working/NMLWhitePaper

[5] Kertajaya, Hermawan. 2008. Arti komunitas . Jakarta: Gramedia Pustaka Utama.

[6] Kotler, Philip \& Gary Armstrong. 2004. Principles of Marketing, 10th edition. New Jersey: Prentice Hall.

[7] Laudon, Kenneth C., Laudon, Jane. 2002. Management Information Systems: Managing The Digital Firm. 7th Edition. Prentice Hall.

[8] Peters, Linda. 1998. The New Interactive Media : One-one, but who to whom?. Marketing Intelligent \& Planning.

[9] Sarwono, Sarlito W. Berkenalan Dengan Aliran-aliran dan Tokoh-Tokoh Psikologi, Jakarta: Bulan Bintang, 2002.

[10] Surjomihardjo, A. 2002. Beberapa Segi Perkembangan Sejarah Pers di Indonesia. Kompas. Jakarta.

[11] Straubhaar \& LaRose. 2008. Media Now: Understanding Media: Understanding Media, Culture, and Technology. Belmont, CA: Wadsworth.

[12] Turban, et.all. 2003. Introduction to Information Technology. $2^{\text {nd }}$ edition. New-York: John Wiley \& Sons.

[13] Vanina Delobelle. 2008. Corporate Community Management. Diambil dari http://www.vaninadelobelle.com.

[14] Wellman, Boase, \& Chen. 2002. The Networked Nature Of Community: Online And Offline. It\&Society, Volume 1, Issue 1, June, Pp. 151-165. 